\title{
VARIATION PATTERNS OF MITOCHONDRIAL DNA OF ABIES ALBA MILL. IN SUTURE ZONES OF POSTGLACIAL MIGRATION IN EUROPE
}

\author{
DUŠAN GÖMÖRY ${ }^{1}$, ROMAN LONGAUER ${ }^{2}$, SASCHA LIEPELT ${ }^{3}$, \\ DALIBOR BALLIAN $^{4}$, RoBert BRUS ${ }^{5}$, HOJKA KRAIGHER ${ }^{6}$, VASIL I. PARPAN ${ }^{7}$, \\ TARAS V. PARPAN ${ }^{7}$, LADislav PAULE ${ }^{1}$, Vladimir I. STUPAR ${ }^{7}$, BIRGIT ZIEGENHAGEN ${ }^{3}$ \\ ${ }^{1}$ Technical University in Zvolen, Faculty of Forestry \\ T.G. Masaryka 24, SK-960 53 Zvolen, Slovakia \\ e-mail: gomory@vsld.tuzvo.sk \\ ${ }^{2}$ Forestry Research Institute
}

T.G. Masaryka 22, SK-960 92 Zvolen, Slovakia

${ }^{3}$ Philipps-University Marburg, Faculty of Biology, Nature Conservation Division

Karl-von-Frisch Str. 2, D-35032 Marburg, Germany

${ }^{4}$ University of Sarajevo

Zagrebačka 20, 71000 Sarajevo, Bosnia and Hercegovina

${ }^{5}$ University of Ljubljana, Biotechnical Faculty

Večna pot 83, SLO-1111 Ljubljana, Slovenia

${ }^{6}$ Slovenian Forestry Institute

Večna pot 2, SLO-1000 Ljubljana, Slovenia

${ }^{7}$ Ukrainian Research Institute for Mountain Forestry

M. Grushevskogo 31, 76000 Ivano-Frankivsk, Ukraine

(Received: August 18, 2003. Accepted: February 3, 2004)

\begin{abstract}
Thirty silver fir populations originating from the putative suture zones of the postglacial recolonization (Slovenia, Bosnia and Hercegovina, Ukraine) were studied using a mitochondrial nad5-4 gene marker. The geographical distribution of mtDNA haplotypes in the Ukrainian Carpathians and their northern foothills indicates a very recent meeting of migration streams arriving from the Romanian Carpathians and Central Europe. In the western part of the Balkan Peninsula, two counterparallel migration streams are the most plausible explanation of the pattern observed. The haplotype typical for the Balkan Peninsula predominates along the Adrian coast, whereas the CentralEuropean haplotype is more represented in the inland.
\end{abstract}

KEY WORDS: Abies alba, mitochondrial DNA, postglacial migration, Balkans.

\section{INTRODUCTION}

Silver fir (Abies alba Mill.) is the most productive native European tree species (Korpel' et al. 1982). In Central Europe (Carpathians, Alps, Hercynic range), its distribution range is relatively continuous, except for marginal regions. On the other hand, disrupted and insular occurrences are typical especially of the Pyrenees, Massif Central, Corsica, Apennines and the southern and southwestern parts of the Balkan Peninsula. Some of these occurrences are extremely small today. For example, the net area of silver fir in $\mathrm{Ca}$ labria is only 11000 ha and it is fragmented into several small insulas (Menguzzato 1988).
Periodical outbursts of the dieback of silver fir are known since the 15th century (Larsen 1986). Whereas at the beginning, the decline was limited to the northern marginal populations in Saxony and Thuringia, since the last century it has been a phenomenon endangering the persistance of local small populations and strongly reducing population sizes in areas with a more continuous occurrence of silver fir over the whole central part of the range. During the last decade, a recovery has been reported from Germany, the Czech Republic, Slovakia and Slovenia, but very probably a new phase of decline will appear again. Conversion of indigenous forests to spruce and pine plantations and the use of silvicultural systems requiring artifi- 
cial reforestation also contributed to a gradual withdrawal of fir from the Central European forests. Gene conservation is thus a relevant issue in silver fir.

Among the factors, shaping the genetic variation in forest trees, the processes associated with the survival of tree population in refugial populations during the Pleistocene glacial periods and the postglacial recolonization of the European continent belong to the most important ones. In addition to paleobotanical investigations, based on the occurrence of fossil pollen and macrofossils (needles, wood, charcoal), genetic evidence can very efficiently be used in the identification of refugia and migration routes. Recent variation patterns in cytoplasmic genes with maternal inheritance, which are thus transferred exclusively by seeds, allow to outline genetically homogeneous areas and make inferences about the migration (Taberlet et al. 1998). In the Pinaceae family, it is the mitochondrial DNA, which generally exhibits maternal inheritance, whereas the chloroplast genes are transferred by the father (Mogensen 1996). Mitochondrial markers have widely been used for reconstructing phylogenies in many conifer species (Gugerli et al. 2001; Johansen and Latta 2003; Mitton et al. 2000; Sinclair et al. 1999; Sperisen et al. 2001).

In an extensive rangewide study of Abies alba Mill., Liepelt et al. (2002) investigated the geographical distribution of haplotypes at an mtDNA locus with two highly conserved alleles, which can be assigned to at least two distinct refugial areas: the Balkans and Central Europe. Since these areas are separated by the treeless Great Hungarian Plain, there are two rather narrow suture zones between them, the eastern one in the Carpathians and the western one in the Dinarian range. However, the suture zones are either underrepresented or even completely unrepresented in the collection. The aim of this study is completing the gaps in these areas of interest and making inferences on the postglacial migration process of silver fir.

\section{MATERIAL AND METHODS}

Samples were collected from 388 trees representing 6 populations from Slovenia, 13 populations from Bosnia and Hercegovina and 11 populations from the Ukrainian Carpathians and their northeastern foothills (Table 1). Only indigenous populations were chosen for sampling. From each population, 10 to 14 adult trees (aged over 80 years) were studied. Dry needles of the 2nd year-class were used for the analyses. To complete the geographic distribution patterns of mtDNA haplotypes in the studied regions, the results presented by Liepelt et al. (2002) for Croatian populations and/or populations from northern Romania, eastern Slovakia and eastern Poland are included in the presentation (Figs 1 and 2).

Total genomic DNA was extracted from 5 to 8 needles per tree, using a modified CTAB protocol following Dumolin et al. (1995). DNA concentration was measured spectrophotometrically.

The assessment of the mtDNA variation followed Liepelt et al. (2002) with slight modifications. The PCR-amplified fragment is located within the fourth intron of the mitochondrial NAD dehydrogenase subunit 5 gene (nad5-4). The PCR mixture contained $1 \times$ PCR buffer (Invitrogen, Frankfurt a.M., Germany), $1.75 \mathrm{mM} \mathrm{MgCl}_{2}, 0.2 \mu \mathrm{M}$ forward and re-
TABLE 1. List of the investigated Abies alba Mill. Populations.

\begin{tabular}{|c|c|c|c|}
\hline Name & Longitude & Latitude & Country \\
\hline Veretskij pereval & $23^{\circ} 10^{\prime}$ & $48^{\circ} 48^{\prime}$ & Ukraine \\
\hline Korostiv & $23^{\circ} 28^{\prime}$ & $49^{\circ} 00^{\prime}$ & Ukraine \\
\hline Sojmy & $23^{\circ} 30^{\prime}$ & $48^{\circ} 32^{\prime}$ & Ukraine \\
\hline Myslivka & $23^{\circ} 42^{\prime}$ & $48^{\circ} 45^{\prime}$ & Ukraine \\
\hline Yasinya & $24^{\circ} 20^{\prime}$ & $48^{\circ} 14^{\prime}$ & Ukraine \\
\hline Yasin'skij pereval & $24^{\circ} 28^{\prime}$ & $48^{\circ} 19^{\prime}$ & Ukraine \\
\hline Nadvirna & $24^{\circ} 35^{\prime}$ & $48^{\circ} 36^{\prime}$ & Ukraine \\
\hline Majdan & $24^{\circ} 36^{\prime}$ & $49^{\circ} 00^{\prime}$ & Ukraine \\
\hline Knyazhdvir & $24^{\circ} 55^{\prime}$ & $48^{\circ} 34^{\prime}$ & Ukraine \\
\hline Berehomet & $25^{\circ} 26^{\prime}$ & $48^{\circ} 12^{\prime}$ & Ukraine \\
\hline Storozhyniets & $25^{\circ} 41^{\prime}$ & $48^{\circ} 08^{\prime}$ & Ukraine \\
\hline Šator & $16^{\circ} 24^{\prime}$ & $44^{\circ} 12^{\prime}$ & Bosnia and Hercegovina \\
\hline Oštrelj & $16^{\circ} 24^{\prime}$ & $44^{\circ} 28^{\prime}$ & Bosnia and Hercegovina \\
\hline Grmeč & $16^{\circ} 39^{\prime}$ & $44^{\circ} 35^{\prime}$ & Bosnia and Hercegovina \\
\hline Busije & $16^{\circ} 50^{\prime}$ & $44^{\circ} 01^{\prime}$ & Bosnia and Hercegovina \\
\hline Prusačka Rijeka & $17^{\circ} 17^{\prime}$ & $44^{\circ} 04^{\prime}$ & Bosnia and Hercegovina \\
\hline Vlašič & $17^{\circ} 41^{\prime}$ & $44^{\circ} 20^{\prime}$ & Bosnia and Hercegovina \\
\hline Kamenica & $18^{\circ} 09^{\prime}$ & $44^{\circ} 22^{\prime}$ & Bosnia and Hercegovina \\
\hline Igman & $18^{\circ} 16^{\prime}$ & $43^{\circ} 47^{\prime}$ & Bosnia and Hercegovina \\
\hline Zvijezda & $18^{\circ} 28^{\prime}$ & $44^{\circ} 13^{\prime}$ & Bosnia and Hercegovina \\
\hline Jahorina & $18^{\circ} 36^{\prime}$ & $43^{\circ} 44^{\prime}$ & Bosnia and Hercegovina \\
\hline Ravna Romanija & $18^{\circ} 42^{\prime}$ & $43^{\circ} 56^{\prime}$ & Bosnia and Hercegovina \\
\hline Petroviči-Klis & $18^{\circ} 44^{\prime}$ & $44^{\circ} 10^{\prime}$ & Bosnia and Hercegovina \\
\hline Sjemeč & $19^{\circ} 10^{\prime}$ & $43^{\circ} 49^{\prime}$ & Bosnia and Hercegovina \\
\hline Trnovski gozd & $13^{\circ} 51^{\prime}$ & $45^{\circ} 58^{\prime}$ & Slovenia \\
\hline Hotedršica & $14^{\circ} 08^{\prime}$ & $45^{\circ} 56^{\prime}$ & Slovenia \\
\hline Kočevlje & $14^{\circ} 58^{\prime}$ & $45^{\circ} 38^{\prime}$ & Slovenia \\
\hline Rajhenavski Rog & $15^{\circ} 01^{\prime}$ & $45^{\circ} 39^{\prime}$ & Slovenia \\
\hline Slovenske Konjice & $15^{\circ} 23^{\prime}$ & $46^{\circ} 20^{\prime}$ & Slovenia \\
\hline Zgornja Velka & $15^{\circ} 46^{\prime}$ & $46^{\circ} 41^{\prime}$ & Slovenia \\
\hline
\end{tabular}

verse primer (for primer sequences, see Liepelt et al. 2002), $0.2 \mu \mathrm{M}$ each dNTP, 0.2 unit Taq DNA polymerase and 25 ng of template DNA. The cycle profile consisted of an initial denaturation at $94^{\circ} \mathrm{C}$ for 3 minutes, followed by 30 cycles of denaturation at $93^{\circ} \mathrm{C}$ for $1 \mathrm{~min}$, annealing at $52.5^{\circ} \mathrm{C}$ for 1 min, and extension at $72^{\circ} \mathrm{C}$ for $1 \mathrm{~min} 20 \mathrm{sec}$, and a final extension step at $72^{\circ} \mathrm{C}$ for $8 \mathrm{~min}$. The amplified fragments were separated by electrophoresis in a $1.2 \%$ agarose gel for 2 hours at $4.5 \mathrm{~V} / \mathrm{cm}(8 \mu \mathrm{l}$ of each PCR product).

\section{RESULTS AND DISCUSSION}

Liepelt et al. (2002) identified two variants of the amplified fragment, differing by an 80 bp insertion/deletion, whereby the type occurring over the major part of the range (central and western Europe) represents the longer variant (allele 1) and the type occurring in the southeastern Europe represents the shorter one (allele 2).

The distribution of mtDNA haplotypes in the Ukrainian Carpathians and their northern foothills is shown in Fig. 1. The boundary between the ranges of both types is unexpectedly sharp in this region. No mixed population samples were found West and Northwest of the line Rakhov-Yasinya-Chernivtsi, all of them contained allele 1 . On the other side of this line, two population samples were fixed for allele 2 and two samples contained a mixture of alleles, but with a strong predominance of allele 2 .

The situation in the suture zone West of the Great Hungarian Plain is slightly different (Fig. 2). The Western-Bosnian populations belong contain predominantly the allele 1. However, to the East of the $16^{\circ} 40^{\prime}$ meridian, all popula- 

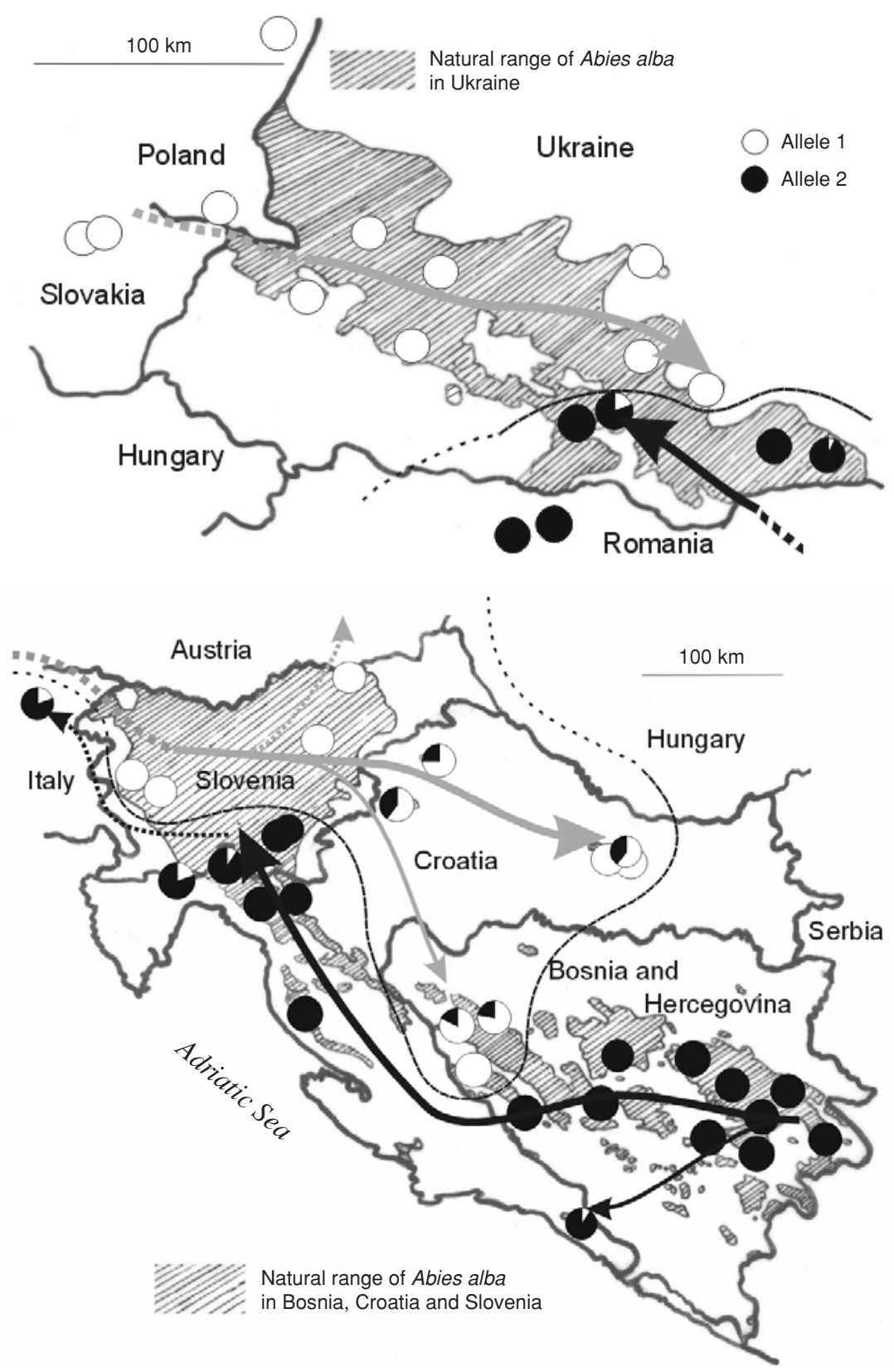

Fig. 1. Frequencies of the nad5-4 haplotypes in the Ukrainian Carpathians including the proposed migration routes (black arrow - migration route of fir originating from the putative North-Apennine refugium, grey arrow - migration route of fir originating from the putative Balkan refugium, dashed line - proposed border between migration streams). Polish, Slovak and Romanian samples taken from Ziegenhagen (unpubl.) and Liepelt et al. (2002). tion samples contained purely the allele 2. In Slovenia, the two North-Dinarian populations were found to be fixed for allele 2, whereas in the populations from the foothills of Alps both in the West and the East of the country, allele 1 predominated strongly. This pattern corresponds to the findings of Liepelt et al., who found the predominance of allele 2 in Dalmatia and a prevalent occurrence of allele 1 in Slavonia and central Croatia.

In both suture zones, the revealed trends correspond completely to those observed in previous studies. In the Eastern and Southern Carpathians in Romania, all the fir populations are fixed for allele 2, whereas Slovak and Polish populations in the Western Carpathians and adjacent hilly regions North of the Carpathian arc exhibit fixation for allele 1 (Liepelt et al. 2002; Ziegenhagen unpubl.). In the western part of the Balkan Peninsula, the pattern is more complicated. Practically all populations are mixed and two parallel clines can be observed: allele 2 is fixed in the southern Balkans populations (Bulgaria), it predominates along the Adriatic coast (from Dalmatia, over Velebit and Kapela Mts., Julian Alps, reaching even northeastern Italy), whereas in the inland (eastern Slovenia, Slavonian hills), allele 1 has generally higher frequencies (Liepelt et al. 2002).

The existence of only two haplotypes in the investigated region of the mitochondrial DNA does not mean that only two glacial refugia existed. In fact, a quite strong differentiation between the southern Balkans (Bulgaria, Macedonia) and the Romanian Carpathians, as well as differences in the representation of regionally specific alleles, indicate rather two (or more) refugial populations in the Balkans, both sharing the same haplotype (Longauer 1996). The same may be true for the central and western Europe.

For the Ukrainian Carpathians, the immigration of fir from the Southeast along the Carpathian arc is generally suggested (Krippel 1986; Środon 1983). The junction of migration streams from the Balkans and the western refugia was supposed at the eastern limit of the Hercynic range (Krippel 1986; Samek 1967). Based on isozyme studies, Konnert and Bergmann (1995) proposed a very broad introgression zone between these migration streams, covering the whole Western Carpathians and Bohemian Quandrangle, and Llamas Gómez and Braun (1995) suppose the influence of the Car- 
pathian silver fir even more westwards (Saxony). The presented results prove that the Carpathian migration stream stopped in fact much more eastern, very close to the presentday state border of Romania and Ukraine. This corresponds well with the results of Longauer (1996), who observed, despite a generally clinal trend of differentiation and allele frequency distribution at isozyme genes, a clear discontinuity between Romanian and Ukrainian Carpathians. Of course, this does not mean that introgression has not taken place, but it is driven more by pollen flow than by seed dispersal, and the center of the introgression zone is located more in the East than originally assumed.

In the western Balkans, Horvat-Marolt and Kramer (1982) proposed the migration of fir from the refugia in Macedonia along the Dinarian range to northern Bosnia and Croatia. Further migration should have been stopped by the presence and strong competition of beech. Konnert and Bergmann (1995) supported this view and suggested a second introgression zone between the populations of Balkan and Central-European origins, covering northwestern Croatia, Slovenia, and southeastern Austria. On the other hand, Kral (1980) admitted the spread of fir originating from the Northern-Apennine refugium from Slovenia towards Slavonia and Dalmatia.

The distribution patterns in the suture zones indicate that the concepts of the glacial and postglacial history of Abies alba, as they have been presented both in paleobotanical and genetical studies, must be slightly revised. The presented results, completed by those of Liepelt et al. (2002) allow to conclude about two counterparallel migration streams in this region. In eastern Bosnia and Bulgaria, populations are fixed for the allele 1, so that probably they were settled from the Balkan refugium. Along the Adriatic coast, fir migrated to the Northwest. In the opposite direction, fir originating from the western refugia occupied the hills between the Sava and Drava rivers, as well as the easternmost part of Bosnia. The introgression zone in the western Balkans is much broader than the Carpathian one, the predominance of populations containing both mitochondrial haplotypes indicates that not only pollen flow, but also seed migration contributed to the introgression. The absence of a sharp border between both haplotypes allows to conclude that the contact of migration streams in the western Balkans must have happened much earlier that in the Carpathians. However, genetic data cannot provide the information on temporal scales of migration.

\section{ACKNOWLEDGEMENTS}

Technical assistance of Christina Mengel (Marburg University) and Sandra Wrobel (Institute for Forest Genetics and Forest Tree Breeding, Grosshansdorf) is heartly appreciated. The study was supported by the EU project Fossilva (EVK2-CT-1999-00036).

\section{LITERATURE CITED}

DUMOLIN S., DEMESURE B., PETIT R.J. 1995. Inheritance of chloroplast and mitochondrial genomes in pedunculate oak investigated with an efficient PCR method. Theoretical and Applied Genetics 91 (8): 1253-1256

GUGERLI F., SENN J., ANZIDEI M., MADAGHIELE A., BÜCHLER U., SPERISEN C., VENDRAMIN G.G. 2001.
Chloroplast microsatellites and mitochondrial nadl intron 2 sequences indicate congruent phylogenetic relationships among Swiss stone pine (Pinus cembra), Siberian stone pine (Pinus sibirica), and dwarf pine (Pinus pumila). Molecular Ecology 10 (6): 1489-1498.

HORVAT-MAROLT S., KRAMER W. 1982. Die Weisstanne (Abies alba Mill.) in Jugoslawien. Forstarchiv 53: 172-180.

JOHANSEN A.D., LATTA R.G. 2003. Mitochondrial haplotype distribution, seed dispersal and patterns of postglacial expansion of ponderosa pine. Molecular Ecology 12: 293-298.

KONNERT M., BERGMANN F. 1995. The geographical distribution of genetic variation of silver fir (Abies alba, Pinaceae) in relation to its migration history. Plant Systematics and Evolution 196: 19-30.

KORPEL'Š., PAULE L., LAFFERS A. 1982. Genetics and breeding of the silver fir (Abies alba Mill.). Annales Forestales 9 (5): 151-184.

KRAL F. 1980. Waldgeschichtliche Grundlagen für die Ausscheidung von Ökotypen bei Abies alba. In: 3. Tannensymposium. Mayer, H. (ed.). Österreichischer Agrarverlag, Wien, pp. 158$-168$.

KRIPPEL E. 1986. Postglaciálny vývoj vegetácie Slovenska. Veda, Bratislava, 307 pp. (In Slovak).

LARSEN J.B. 1986. Das Tannensterben: Eine neue Hypothese zur Klärung des Hintergrundes dieser rätselhaften Komplexkrankheit der Weisstanne (Abies alba Mill.). Forstwissenschaftliches Centralblatt 105: 381-396.

LIEPELT S., BIALOZYT R., ZIEGENHAGEN B. 2002. Winddispersed pollen mediates postglacial gene flow among refugia. Proceedings of the National Academy of Sciences of the United States of America 99 (22): 14590-14594.

LLAMAS GÓMEZ L., BRAUN H. 1995. Die Weißtanne (Abies alba Mill.) in Sachsen unter besonderer Berücksichtigung ihrer genetischen Konstitution. In: Genetik und Waldbau der Weißtanne. Teil 1. Schriftenreihe der Sächsischen Landesanstalt für Forsten, pp. 5-19.

LONGAUER R. 1996. Genetic diversity of European silver fir (Abies alba Mill.). PhD thesis, Technická univerzita vo Zvolene, Zvolen, $154 \mathrm{pp}$.

MENGUZZATO G. 1988. Möglichkeiten und Grenzen der Tanne in Kalabrien. In: 5. IUFRO-Tannensymposium, Zvolen. Paule L., Korpel' Š. (eds.). pp. 163-166.

MITTON J.B., KREISER B.R., LATTA R.G. 2000. Glacial refugia of limber pine (Pinus flexilis James) inferred from the population structure of mitochondrial DNA. Molecular Ecology 9: 91-97

MOGENSEN H.L. 1996. The hows and whys of cytoplasmic inheritance in seed plants. American Journal of Botany 83 (3): 383-404.

SAMEK V. 1967. O šíření jedle bílé (Abies alba Mill.) v době poledové na území střední Evropy. Lesnícky časopis 13 (7): 659-666. (In Czech).

SINCLAIR W.T., MORMAN J.D., ENNOS R.A. 1999. The postglacial history of Scots pine (Pinus sylvestris L.) in western Europe: evidence from mitochondrial DNA variation. Molecular Ecology 10: 83-88.

SPERISEN C., BÜCHLER U., GUGERLI F., MÁTYÁS G., GEBUREK T., VENDRAMIN G.G. 2001. Tandem repeats in plant mitochondrial genomes: application to the analysis of population differentiation in the conifer Norway spruce Molecular Ecology 10 (1): 257-264.

ŚRODOŃ A. 1983. Jodła pospolita w historii naszych lasów. In: Jodła pospolita Abies alba Mill. Białobok, S. (ed.). Państwowe Wydawnictwo Naukowe, Warszawa-Poznań, p. 9-39. (In Polish)

TABERLET P., FUMAGALLI L., WUST-SAUCY A.-G., COSSON J.-F. 1998. Comparative phylogeography and postglacial colonization routes in Europe. Molecular Ecology 7 (4): 453-464 . 